\title{
Photosynthetically-Competent Phytoplankton from the Aphotic Zone of the Deep Ocean
}

\author{
T. Platt, D. V. Subba Rao, J. C. Smith, W. K. Li., B. Irwin, E. P. W. Horne and D. D. \\ Sameoto
}

Marine Ecology Laboratory, Bedford Institute of Oceanography, Dartmouth, Nova Scotia B2Y 4A2, Canada

\begin{abstract}
Comparison of 2 water samples, one collected from $10 \mathrm{~m}$, the other from the aphotic zone $(1000 \mathrm{~m})$ on the Costa Rica Dome in the eastern tropical Pacific Ocean, revealed the presence in both samples of pigmented cells of several diatoms, dinoflagellates and coccoid organisms. Measurements of carbon assimilation rates in temperature-controlled incubators across a light gradient demonstrated that the assimilation number ( $\mathrm{mg} \mathrm{C}[\mathrm{mg} \mathrm{Chl} \mathrm{a}]^{-1} \mathrm{~h}^{-1}$ ) of the $1000 \mathrm{~m}$ sample was about 0.8 , similar to that of the $10 \mathrm{~m}$ sample. The ratios of RuBP carboxylase to other carboxylating enzymes were also similar between $10 \mathrm{~m}$ and the aphotic zone. However, the initial slope $\alpha$ and the inhibition parameter $\beta$ were considerably higher for the deep sample than for the $10 \mathrm{~m}$ sample. Possible mechanisms by which these viable algae reached the aphotic zone are discussed.
\end{abstract}

\section{INTRODUCTION}

The existence of chlorophyll-containing microorganisms has been reported at various times in samples from the aphotic zone of the oceans (Wood, 1956; Kimball et. al., 1963; Fournier, 1966, 1970, 1971; Hamilton et. al., 1968; Kimor and Wood, 1975; Silver and Bruland, 1981) and from deep-sea sediments (Malone et al., 1973). Although some authors have speculated on the possible origin and ecological role of these pigmented organisms, their photosynthetic competence has not, to our knowledge, been tested. We have found that the photosynthetic response of populations, measured immediately on bringing the samples up from $1000 \mathrm{~m}$, resembled that of near-surface populations sampled at the same station, on the Costa Rica Dome (Wyrtki, 1964) in the eastern tropical Pacific Ocean. This observation of photosynthetic competence in populations from great depth raises important questions about the dynamics of the ocean ecosystem.

\section{METHODS AND RESULTS}

Experiments were done during a cruise of CSS 'Hudson' in March and April 1981 (Longhurst, 1981). The Costa Rica Dome station was located at $09^{\circ} 13^{\prime} \mathrm{N}$; $89^{\circ} 28^{\prime} \mathrm{W}$, roughly 300 nautical miles from the coast, depth $3200 \mathrm{~m}$. Samples were taken on 27 March from $10 \mathrm{~m}$ using a submersible pumping system (Herman, unpubl.) and from $1000 \mathrm{~m}$ using a 30-1 Niskin bottle. The possibility that the deep sample bottle had closed prematurely in the surface layer could be discounted with confidence by reference to the sample temperature. Procedures to determine the photosynthetic response $\left({ }^{14} \mathrm{C}\right.$ technique) to available light were begun immediately after the samples came onto the ship. Experiments were done in temperature-controlled incubators using methods described elsewhere (Platt et al., 1982, in press). A net tow made by the BIONESS closing net system (Sameoto et al., 1980) equipped with $30 \mu \mathrm{m}$ mesh nets was obtained from the 950-1000 $\mathrm{m}$ depth stratum.

In the $30 \mu \mathrm{m}$-net samples we found pigmented cells of the diatoms: Actinoptychus undulatus (Bailey) Ralfs, Chaetoceros peruvianum Brightwell, Corethron hystrix Hensen, Coscinodiscus sp., Nitzschia seritata Cleve, Planktoniella sol(Wallich) Schutt, Pleurosigma sp., Rhizosolenia alata Brightwell, Thalassionema nitzschioides Grunow, Thalassiosira sp. Ehrenberg; and the dinoflagellates: Dinophysis caudata SavilleKent, D. ovum Schütt, D. urocantha Stein, Gymnodinium sp., Oxytoxum scolopax Stein, Peridinium oceanicum Van höffen, Podolampas spinifer Okamura and Prorocentrum micans Ehrenberg. Unidentified round green cells $(\approx 20 \mu \mathrm{m})$, coccoid cells $(\approx 1 \mu \mathrm{m})$ and 
some fecal pellets were also present in the samples. The species assemblage from $1000 \mathrm{~m}$ was not unlike that seen in the near surface sample. The pigmented cells fluoresced red (low-wavelength-cut-off, emission filter $530 \mathrm{~nm}$ ) when observed in the transmitted light fluorescence microscope under excitation at $420 \mathrm{~nm}$.

The light-saturation curves were fitted by statistical methods to an empirical representation of the photosynthetic response (Platt et al., 1980). The equation is

$$
\mathrm{P}^{\mathrm{B}}(\mathrm{I})=\mathrm{P}_{\mathrm{s}}^{\mathrm{B}}\left(1-\mathrm{e}^{-\alpha \mathrm{L} / \mathrm{P}^{\mathrm{B}}}\right) \mathrm{e}^{-\beta \mathrm{B} / \mathrm{P}_{\mathrm{B}}^{\mathrm{B}}},
$$

where $\mathrm{I}=$ available light $\left(\mathrm{W} \mathrm{m}^{-2}\right) ; \mathrm{P}=$ carbon fixation

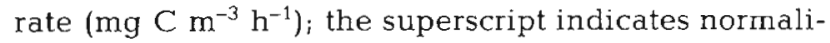
zation to chlorophyll a biomass $\mathrm{B}\left(\mathrm{mg} \mathrm{Chl} \mathrm{a} \mathrm{m}^{-3}\right)$. The parameter $\mathrm{P}_{\mathrm{s}}^{\mathrm{B}}$ is the maximum photosynthetic rate that would be achieved under the existing conditions by the experimental assemblage of phytoplankton if there were no photoinhibition; the parameter $\alpha$ is the slope of $\mathrm{P}^{\mathrm{B}}(\mathrm{I})$ as $\mathrm{I}$ tends to zero. The other parameter, $\beta$, indicates the strength of the photoinhibition. The derived parameter

$$
\mathrm{P}_{\mathrm{m}}^{\mathrm{B}}=\mathrm{P}_{\mathrm{s}}^{\mathrm{B}}\left(\frac{\alpha}{\alpha+\beta}\right)\left(\frac{\beta}{\alpha+\beta}\right)^{\beta / \alpha}
$$

corresponds to the assimilation number, commonly used in the phytoplankton literature.

The photosynthesis-light curves are shown in Fig. 1. The curve for the $1000 \mathrm{~m}$ sample is quite similar to that for the $10 \mathrm{~m}$ sample, in both shape and amplitude. The assimilation numbers for the deep and shallow samples at the Costa Rica Dome differed by little (Table 1). Both the initial slope $\alpha$ and the inhibition parameter $\beta$ were considerably higher for the deep sample compared to the shallow one. On the other hand, the irradiance for optimal photosynthesis $\left(I_{m}\right.$ a derived parameter of the empirical model) was lower. The differences in $I_{m}$ and $\beta$ are in the sense expected for a dark-adapted population but the difference in $\alpha$ (normalized to chlorophyll) is not (Platt et al., in press).

The activities of several carboxylating enzymes were determined using material from $500 \mathrm{ml}$ aliquots filtered onto $2.4 \mathrm{~cm}$ GFF (Whatman; $0.5 \mu \mathrm{m}$ nominal pore size) filters. The enzymes ribulose bisphosphate car- boxylase (RuBPC: E. C. 4. 1. 1. 39), phosphoenolpyruvate carboxylase (PEPC: E. C. 4, 1.1.31), phosphoenolpyruvate carboxykinase (PEPCK: E. C. 4. 1. 1. 49) and pyruvate carboxylase (PYC: E. C. 6. 4.1.1) were assayed in quadruplicate. Enzyme activities were determined radiometrically by measuring the incorporation of ${ }^{14} \mathrm{CO}_{2}$ or $\mathrm{H}^{14} \mathrm{CO}_{3}{ }^{-}$into acid stable products in vivo. The cells on the filters were made permeable to substrates by using lysolecithin (Sigma, Type 1) after the method of Miller et al. (1978). The RuBPC and

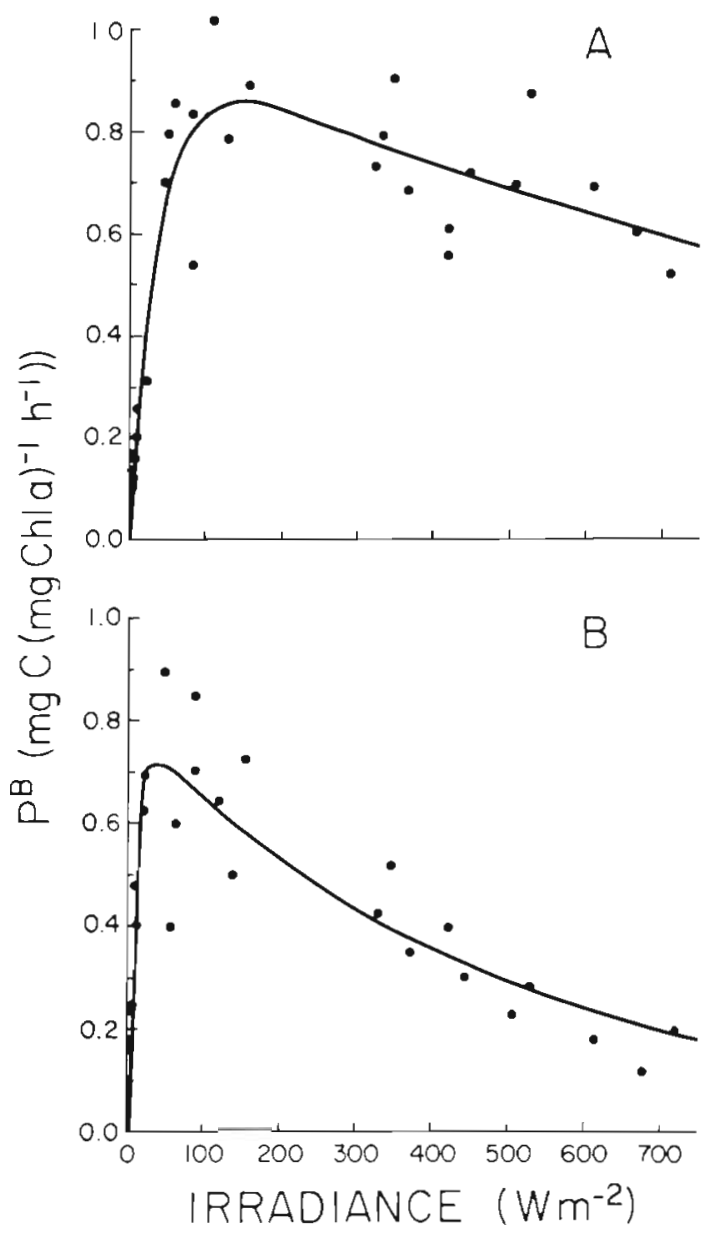

Fig. 1. Photosynthesis light curves. (A) for $10 \mathrm{~m}$ sample; (B) for $1000 \mathrm{~m}$ sample

Table 1. Fitted parameters" for photosynthesis light curves from phytoplankton samples taken in the eastern tropical Pacific Ocean. Two derived parameters are also given

\begin{tabular}{ccccrr}
\hline Sample & $\mathrm{P}_{\mathrm{s}}^{\mathrm{B}}$ & $\alpha$ & $\beta$ & $\mathrm{P}_{\mathrm{m}}^{\mathrm{B}}$ & $\mathrm{I}_{\mathrm{m}}$ \\
\hline Costa Rica Dome $10 \mathrm{~m}$ & 0.95 & 0.024 & 0.0007 & 0.84 & 142 \\
Costa Rica Dome 1000 m & 0.78 & 0.084 & 0.0016 & 0.72 & 37
\end{tabular}

- Average coefficients of variation of the parameters are about $8 \%$ for $P_{s}^{B}, 16 \%$ for $\alpha$, and $45 \%$ for $\beta$. Photosynthesis $P$ has units $\mathrm{mg} C$ fixed ( $\mathrm{mg} \mathrm{Chl} a)^{-1} ; \mathrm{I}$ is $\mathrm{Wm}^{-2} ; \alpha$ and $\beta$ have units of $\mathrm{P} / \mathrm{I}$ 
PEPC methods are similar to those of Mukerji and Morris (1976). The PEPCK method is similar to that for PEPC with $\mathrm{Mg}^{++}$replaced by $\mathrm{Mn}^{++}$and ADP while for PYC, PEP was replaced by ATP and pyruvate. The PYC method of Appelby et al. (1980) was adapted for the in vivo procedure here.

The proportion of RuBPC activity $\left(C_{3}\right.$ carbon fixation) to that of the other carboxylating enzyme activities $\left(\mathrm{C}_{4}\right.$ or $\beta$ carbon fixation) is strikingly similar at 10 and at $1000 \mathrm{~m}$ (Table 2). This qualitative similarity in the biochemical machinery of the cells may indicate that both the species assemblage and adaptive state of the organisms at both depths is comparable, possibly implying that at the Costa Rica Dome there exists a rapid means of transporting phytoplanktion cells from the surface to $1000 \mathrm{~m}$.

\section{DISCUSSION}

We now inquire into the possible mechanisms by which these viable cells reached the aphotic zone. In this context, the age of the water at $1000 \mathrm{~m}$ is of interest. Fig. 2 shows that this depth is near the bottom of the oxygen minimum layer. Reid (1965) shows that the water mass originates in the northern Pacific with an $\mathrm{O}_{2}$ content $\approx 5 \mathrm{ml} \mathrm{l}^{-1}$. The $1000 \mathrm{~m}$ water had an $\mathrm{O}_{2}$ content of $0.2 \mathrm{ml} \mathrm{l}^{-1}$ : using the apparent oxygen utilization rate (AOUR) for a $1000 \mathrm{~m}$ sample from the Atlantic (Jenkins, 1980) of $0.035 \mathrm{ml} \mathrm{l}^{-1} \mathrm{yr}^{-1}$ we can estimate a maximum age for the water of $134 \mathrm{yr}$. A minimum estimate can be found by applying a surface AOUR of $0.5 \mathrm{ml} \mathrm{l}^{-1} \mathrm{yr}^{-1}$ to give an age of $9 \mathrm{yr}$, but the higher estimate is probably much closer to the truth.

The net downward velocity of phytoplankton cells due to their negative buoyancy is also relevant. The similarity in phytoplankton community structure between near surface and deep samples in the Costa Rica Dome leads one to estimate a mixing rate based on velocity shear. Drogue measurements at the station indicated horizontal velocities at the surface of $\approx 0.5 \mathrm{~m} \mathrm{~s}^{-1}$. Assuming zero horizontal velocity at $1000 \mathrm{~m}$ we then get a mean horizontal velocity over the water column of $0.25 \mathrm{~m} \mathrm{~s}^{-1}$. Therefore, taking the Dome to be $300 \mathrm{~km}$ in diameter, for a cell originating in the surface layer of the Dome to sink to $1000 \mathrm{~m}$

Table 2. Enzyme activities (n moles $\mathrm{CO}_{2}$ or $\mathrm{HCO}_{3}$ fixed $\mathrm{h}^{-1} \mathrm{l}^{-1}$ ) referred to $25^{\circ} \mathrm{C}$, and some ratios thereof for samples from the eastern tropical Pacific Ocean. $\Sigma$ P is the sum of PEPC, PEPCK and PYC

\begin{tabular}{|cccccc|}
\hline Sample & RuBPC & RuBPC/PEPC & RuBPC/PEPCK & RuBPC/PYC & RuBPC/IP \\
\hline Costa Rica Dome $10 \mathrm{~m}$ & 260 & 1.15 & 2.57 & 11.2 & 0.744 \\
Costa Rica Dome $1000 \mathrm{~m}$ & 4.55 & 1.14 & 3.03 & 20.2 & 0.798 \\
\hline
\end{tabular}
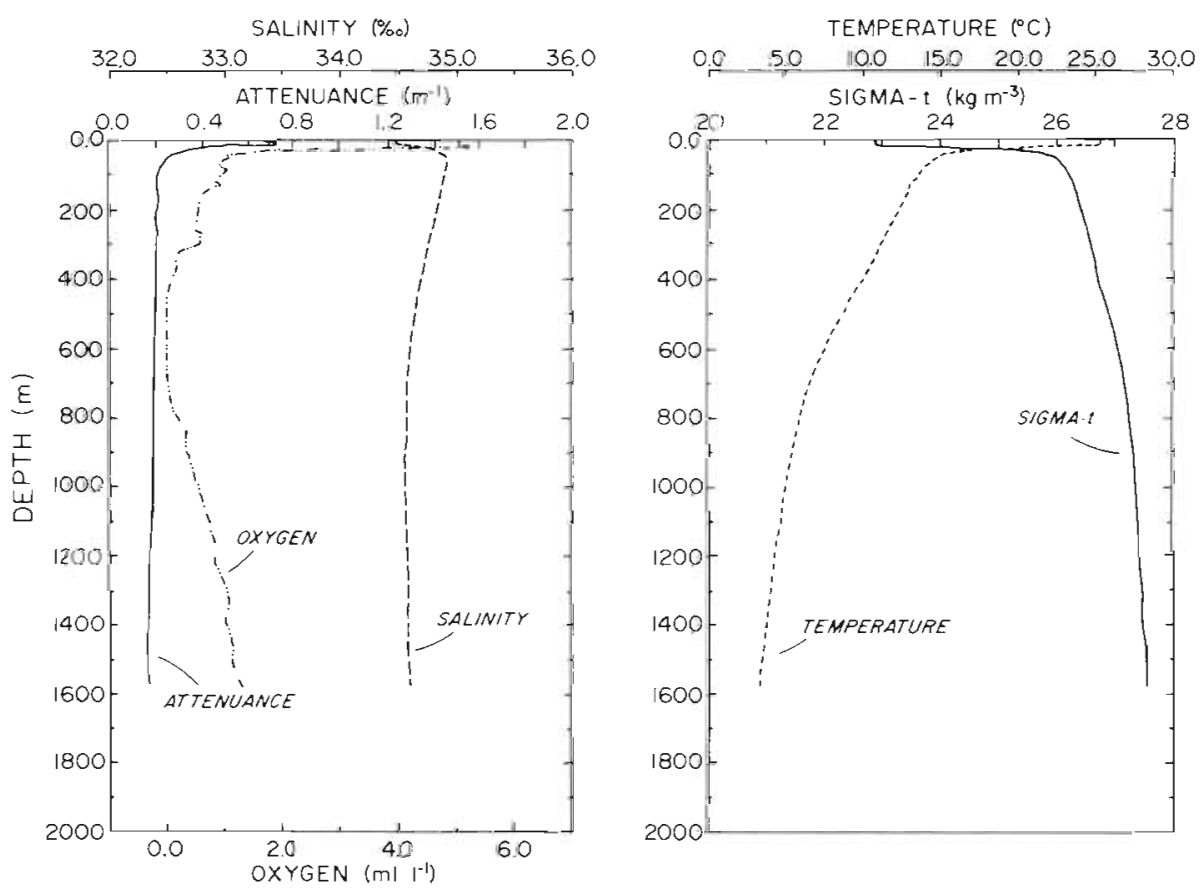

Fig. 2. Attenuance, oxygen, temperature and sigma-t profiles at the Costa Rica Dome 
before it is advected out of the Dome area it must be sinking at a minimum velocity of

$$
\frac{1000 \times 0.25 \times 86400}{300 \times 10^{3}}=72 \mathrm{~m} \mathrm{~d}^{-1}
$$

On the other hand, recent measurements of sinking of phytoplankton in the subtropical ocean (Bienfang, 1980) give rates of only $2 \mathrm{~m} \mathrm{~d}^{-1}$.

A possible mechanism to reconcile these grossly different estimates of sinking rate stems from the view, for which there is increasing support, that a major proportion of the downward transport of biological material in the ocean is in the form of aggregates of cells, rather than individual cells, either packaged as the fecal pellets of herviborous heterotrophs (Schrader, 1971; Smayda, 1971; Bishop et al., 1977; Silver and Bruland, 1981; Bruland and Silver, 1981; Deuser et al., 1981; Dunbar and Berger, 1981; Sasaki and Nishizawa, 1981; Urrère and Knauer, 1981) or through their being impacted and carried down by other large particles, biogenic or otherwise, sinking at higher Stokes'velocities than those appropriate to individual phytoplankton cells (Honjo, 1980; Lal, 1980; Fellows et al., 1981; Silver and Alldredge, 1981). For example, Bruland and Silver (1981) estimated sinking rates of pellets from doliolids at $\approx 208 \mathrm{~m} \mathrm{~d}^{-1}$, from pteropods at $1800 \mathrm{~m} \mathrm{~d}^{-1}$ and from salps at $2700 \mathrm{~m} \mathrm{~d}^{-1}$. Small et al. (1979) estimate up to $225 \mathrm{~m} \mathrm{~d}^{-1}$ for fecal pellets of copepods and up to $900 \mathrm{~m} \mathrm{~d}^{-1}$ for those from euphausiids. Fecal material was observed in the $30 \mu \mathrm{m}$-net tows, but its taxonomic origin could not be identified with certainty.

At these accelerated rates, possibly accentuated by vertical migration of the herbivores, phytoplankton would have little difficulty in sinking to $1000 \mathrm{~m}$ in times $\approx 1 \mathrm{~d}$. Further, it is known (Porter, 1973) that some algal cells can remain viable after passing through zooplankton guts, and there has even been a recent report of photosynthesis by phytoplankton while still inside the zooplankton exoskeleton (Epp and Lewis, 1981). Enhanced downward transportation may then be a mechanism for seeding the aphotic zone with metabolically-competent phytoplankton, particularly if fecal pellets suffer disintegration at great depth (Silver and Alldredge, 1981; Silver and Bruland, 1981).

In the short term, the rates of enzyme catalyzed reactions are affected by pressure according to its effect on the volume of the system containing the activited enzyme substrate complex. Low and Somero (1975) have pointed out that the volume changes for particular enzyme reactions may be positive, negative or zero, but in any case would be quite small relative to the effect of the temperature decrease associated with transport from 10 to $1000 \mathrm{~m}$. However, one might expect some sort of cellular adjustment in the long term. The similarity of the assimilation number of the
$1000 \mathrm{~m}$ sample, measured at sea level pressure, with that of the $10 \mathrm{~m}$ sample, implies that any pressure response was reversible, that internal adjustment had not occurred, and favours the argument that the cells had been transported rapidly to the aphotic zone.

Although the RuBPC values at $1000 \mathrm{~m}$ at the Dome are very substantial, we must face the question, in the light of the much smaller differences in the levels of the light saturation curve parameters (Table 1), of why these values are only about one sixtieth of those at $10 \mathrm{~m}$. An attractive ad hoc hypothesis is that the carboxylating enzymes may serve another function in addition to their catalytic role in carboxylation. The large amount of nitrogen associated with chlorophyllprotein complexes (Alberte et al., 1977; Perry et al., 1981) and RuBPC (Huffaker and Peterson, 1974; Bolton and Brown, 1980) has led to the suggestion that these substances may serve as reserves of nitrogen which are utilized during nitrogen unavailability. Perhaps the carboxylating enzymes in this case are present in excess and are able to serve as an energy store when light is unavailable.

The finding of substantial amounts of RuBPC at depth in the eastern tropical Pacific is similar to the result of Vincent (1978) for Lake Tahoe who also found that aphotic, lacustrine phytoplankton were able to photosynthesize immediately on exposure to light, at a rate which did not increase significantly in response to preincubation in the light for up to $116 \mathrm{~h}$.

The immediate photosynthetic response of cells taken from the aphotic zone, the fact that they could realize light-saturated rates of photosynthesis comparable with those of cells from the surface layer, support, but are not enough to prove, the conjecture that the cells had sunk to $1000 \mathrm{~m}$ in a few days rather than a few years. It is difficult to accept, from considerations of energetics, the alternative explanation that the cells had been surviving heterotrophically in aphotic conditions for several years but nevertheless maintained the metabolic apparatus of photosynthesis ready for an immediate response to increased illumination (see Smayda and Mitchell-Innes, 1974). There is supporting evidence for this. Laboratory studies on several phytoplankton cultures have demonstrated retention of normal growth and immediate resumption photosynthetic capacity following extended (up to $25 \mathrm{w}$ ) incubation in darkness (Handa, 1969; Antia and Cheng, 1970; Griffiths, 1973).

To test for heterotrophic activity in the phytoplankton from $1000 \mathrm{~m}$, we measured incorporation of tritiated glucose and of a mixture of tritiated amino acids formulated to resemble a typical algal protein hydrolysate (New England Nuclear Corp., Net-250). The turnover rate of amino acids due to incorporation by material filterable onto a $1 \mu \mathrm{m}$ Nuclepore membrane was 
$0.05 \pm 0.04 \% \mathrm{~d}^{-1}$, equivalent to a turnover time of $\approx 2000 \mathrm{~d}$. In comparison, the activity due to material passing a $1 \mu \mathrm{m}$ membrane filter ('bacterioplankton') was $1.31 \pm 0.55 \% \mathrm{~d}^{-1}$. In the case of glucose, incorporation was measurable only in the bacterioplankton fraction $\left(0.14 \pm 0.19 \mathrm{~d}^{-1}\right)$. Hence the heterotrophic activity at $1000 \mathrm{~m}$ appears to reside only in the unattached bacteria; the vanishingly low rates in the larger size fraction (nanoplankton) argue against the existence of a phytoplankton population in the aphotic zone that maintains itself through heterotrophic metabolism.

\section{LITERATURE CITED}

Alberte, R. S., Thornber, J. P., Fiscus, E. L. (1977). Water stress effects on the content and organization of chlorophyll in mesophyll and bundle sheath chloroplasts of maize. Plant. Physiol. 59: 351-353

Antia, N. J., Cheng, J. Y (1970). The survival of axenic cultures of marine planktonic algae from prolonged exposure to darkness at $20^{\circ} \mathrm{C}$. Phycologia 9: 179-183

Appleby, G., Colbeck, J., Holdsworth, E. S, Wadman, H. (1980). $\beta$-carboxylation enzymes in marine phytoplankton and isolation and purification of pyruvate carboxylase from Amphidinium carterae (Dinophyceae). J. Phycol. 16: 290-295

Bienfang, P. K. (1980). Phytoplankton sinking rates in oligotrophic waters off Hawaii, USA. Mar. Biol, 61: 69-77

Bishop, J. K. B., Edmond, J. M., Ketten, D. R., Bacon, M. P., Wilker, W. B. (1977). The chemistry, biology, and vertical flux of particulate matter from the upper $400 \mathrm{~m}$ of the equatorial Atlantic Ocean. Deep Sea Res. 24: 511-548

Bolton, J. K., Brown, R. H. (1980). Photosynthesis of grass species differing in carbon dioxide fixation pathways 5 . Response of Panicum maximum, Panicum milloides and tall fescue Festuca arundinacea to nitrogen. Plant. Physiol. 66 (11): $97-100$

Bruland, K. W., Silver, M. W (1981). Sinking rates of fecal pellets from gelatinous zooplankton (Salps, Pteropods, Doliolids). Mar. Biol. 63: 295-300

Deuser, W. G., Ross, E. H., Anderson, R. J. (1981). Seasonality in the supply of sediment to the deep Sargasso Sea and implications for the rapid transfer of matter to the deep ocean. Deep Sea Res. 28A (5): 495-505

Dunbar, R. B., Berger, W. H. (1981). Fecal pellet flux to modern bottom sediment of Santa Barbara Basin (California) based on sediment trapping. Geological Society of America Bulletin, Part. 1, 92: 212-218

Epp, R. W., Lewis, W. M., Jr. (1981). Photosynthesis in copepods. Science, N. Y. 214: 1349-1350

Fellows, D. A., Karl, D. M., Knauer, G. A. (1981). Large particle fluxes and the vertical transport of living carbon in the upper $1500 \mathrm{~m}$ of the northeast Pacific Ocean. Deep Sea Res, 28A (9): 921-936

Fournier, R. O. (1966). North Atlantic deep-sea fertility. Science, N. Y 153: 1250-1252

Foumier, R. O. (1970). Studies on pigmented microorganisms from aphotic marine environments. Limnol. Oceanogr. 15 $675-682$

Fournier, R. O. (1971). Studies on pigmented microorganisms from aphotic marine environments. II. North Atlantic distribution. Limnol. Oceanogr. 16: 952-961
Griffiths, D. J. (1973). Factors affecting the photosynthetic capacity of laboratory cultures of the diatom. Phaeodactytum tricornatum. Mar. Biol. 21: 91-97

Hamilton, R. D., Holm-Hansen, O., Strickland, J. D. H. (1968). Notes on the occurrence of living microscopic organisms in deep water. Deep Sea Res. 15: 651-656

Handa, N. (1969). Carbohydrate metabolism in the marine diatom Skeletonema costatum. Mar. Biol. 4: 208-214

Herman, A. W. (Unpublished). Bedford Institute of Oceanography, unpublished manuscript

Honjo, S. (1980). Material fluxes and modes of sedimentation in the mesopelagic and bathpelagic zone. J. mar Res. 38 (1): 53-97

Huffaker, R. C., Peterson, L. W. (1974). Protein turnover in plants and possible means of its regulation. Ann. Rev. Pl. Physiol. 25: 363-392

Jenkins, W. J. (1980). Tritiums and ${ }^{3} \mathrm{He}$ in the Sargasso Sea. J. mar. Res. 38: 533-569

Kimball, J. F., Jr., Corcoran, E. F., Wood, E. J. F. (1963) Chlorophyll - containing microorganisms in the aphotic zone of the oceans. Bull. mar. Sci. Gulf Caribb. 13: $574-577$

Kimor, B., Wood, E. J. F. (1975). A plankton study in the eastern Mediterranean Sea. Mar. Biol. 29: 321-333

Lal, D. (1980). Comments on some aspects of particulate transport in the oceans. Earth Planet. Sci. Lett. 49: 520-527

Longhurst, A. (1981). Biostat: an experiment of ocean plankton ecology cruise report for Hudson 81 Panama to Puntarenas). Report Series/BI-R-81-13/Sept. 81

Low, P. S., Somero, G. N. (1975). Pressure effects on enzyme structure and function in vitro and under simulated in vivo conditions. Comp. Biochem. Physiol. 52B: 67-74

Malone, T. C., Garside, C., Anderson, R., Roels, O. A. (1973). The possible occurrence of photosynthetic microorganisms in deep-sea sediments of the North Atlantic. J. Phycol. 9: $482-488$

Miller, M. R., Castellot, J. J. JT, Pardee, A. B. (1978). A permeable animal cell preparation for studying macromolecular synthesis. DNA synthesis and the role of deoxy ribonucleotides in $\mathrm{S}$ phase initiation. Biochemistry 17 . 1073-1080

Mukerji, D., Morris, I. (1976). Photosynthetic carboxylating enzymes in Phaeodactylum tricornutum: assay methods and properties. Mar. Biol. 36: 199-206

Perry, M. J., Larsen, M. C., Alberte, R. S. (1981). Photoadaptation in marine phytoplankton: Response of the photosynthetic unit. Mar. Biol. 62: 91-101

Platt, T., Gallegos, C. L., Harrison, W. G. (1980). Photoinhibition of photosynthesis in natural assemblages of marine phytoplankton. J. mar. Res. 38 (4): 687-701

Platt, T., Harrison, W G., Irwin, B., Horne, E. P. (1982) Photosynthesis and photoadaptation of marine phytoplankton in the Arctic. Deep Sea Res., in press

Porter, K. G. (1973). Selective grazing and differential digestion of algae by zooplankton. Nature, Lond. 244: 179-180

Reid, J. L., Jr. (1965). Intermediate waters of the Pacific Ocean. The Johns Hopkins Oceanographic Studies, No. 2, Baltimore, Johns Hopkins University Press

Sameoto, D. D., Jaroszysnki, L. O., Fraser, W. B. (1980) Bioness, a new design in multiple net zooplankton samplers. Can. J. Fish. Aquat. Sci. 37 (4): 722-724

Sasaki, H., Nishizawa, S. (1981). Vertical flux profiles of particulate material in the Sea off Sanriku. Mar. Ecol. Prog. Ser. 6: 191-201

Schrader, H. J. (1971). Fecal pellets: role in sedimentation of pelagic diatoms. Science, N. Y. 174: 55-77

Silver, M. W., Alldredge, A. L. (1981). Bathypelagic marine 
snow: deep-sea algal and detrital community. J. mar. Res. 39 (3) : 501-530

Silver, M. W., Bruland, K. W. (1981). Differential feeding and fecal pellet composition of salps and pteropods, and the possible origin of the deep-water flora and olive-green 'Cells'. Mar. Biol. 62: 263-273

Small, L. F., Fowler, S. W., Unluv, M. Y. (1979). Sinking rates of natural fecal pellets. Mar. Biol. 51: 223-241

Smayda, T J. (1971). Normal and accelerated sinking of phytoplankton in the sea. Mar. Geol. 11: 105-122

Smayda, T. J., Mitchell-Innes, B. (1974). Dark survival of autotrohpic, planktonic marine diatoms. Mar. Biol, 25:
195-202

Urrère, M. A., Knauer, G. A (1981). Zooplankton fecal pellet fluxes and vertical transport of particulate organic material in the pelagic environment. J. Plankton Res. 3 (3): 369-387

Vincent, W. F. (1978). Survival of aphotic phytoplankton in Lake Tahoe throughout prolonged stratification. Verh. Internat. Verein. Limnol. 20: 401-406

Wood, E. J. F. (1956). Diatoms in the ocean deeps. Pacific Sci. 10: $377-381$

Wyrtki, K. (1964). Upwelling in the Costa Rica Dome. Fish. Bull. U. S. 63 (2): $355-372$

This paper was submitted to the editor; it was accepted for printing on August 26, 1982 